Vol 10, Issue 12, 2017

\title{
EFFECT OF ETHANOLIC EXTRACT OF CYANOTIS CRISTATA LEAVES APPLIED TOPICALLY ON WOUND HEALING IN WISTAR RATS
}

\author{
ANURAG PATHAK ${ }^{1}$, SMITA SHENOY ${ }^{1 *}$, SUSHIL KIRAN ${ }^{1}$, AVINASH ARIVAZAHAN ${ }^{1}$, DEEPAK NAYAK ${ }^{2}$, \\ NAVEEN KUMAR ${ }^{3}$, AMOD TILAK ${ }^{1}$, MANJUNATH SHETTY ${ }^{4}$
}

${ }^{1}$ Department of Pharmacology, Kasturba Medical College, Manipal University, Manipal, Karnataka, India. ${ }^{2}$ Department of Pathology, Kasturba Medical College, Manipal University, Manipal, Karnataka, India. ${ }^{3}$ Department of Anatomy, Melaka Manipal Medical College, Manipal University, Manipal, Karnataka, India. ${ }^{4}$ Department of Pharmacology, Melaka Manipal Medical College, Manipal University, Manipal, Karnataka, India. Email: smita.shenoy@manipal.edu

Received: 15 June 2017, Revised and Accepted: 12 August 2017

ABSTRACT

Objective: The objective of this study was to assess the effect of ethanolic extract of Cyanotis cristata leaves when applied topically on healing of wound in Wistar rats.

Methods: C. cristata leaves were evaluated for its effect on healing of wound in three models, namely, incision, excision, and burn wound. Each model included five groups, each consisting of 6 rats. The five groups were as follows: Group I rats (control and ointment base), Group II rats (standard and silver sulfadiazine), and Group III, Group IV, Group V (treated with C. cristata extract ointment of $0.5 \%, 1 \%$, and $2 \%$, respectively). Variables evaluated included breaking strength in incision wound while it was contraction rate and epithelialization in excision and burn wound. One-way analysis of variance and Tukey's post hoc test was used to analyze data.

Result: In incision wound, breaking strength in test group was significantly increased ( $p<0.001$ ) as compared to control. In excision and burn wound of test group, time to epithelialization and contraction rate was significantly decreased $(p<0.001)$. The granulation tissue from excision and burn wound showed increased collagen and less inflammatory cells in test groups in comparison to the control.

Conclusion: The ethanolic extract of leaves of $C$. cristata, when applied topically, enhanced wound strength and accelerated healing of incision, excision, and burn wounds in rats.

Keywords: Incision wound, Excision, Burn wound, Breaking strength, Contraction, Epithelialization.

(C) 2017 The Authors. Published by Innovare Academic Sciences Pvt Ltd. This is an open access article under the CC BY license (http://creativecommons. org/licenses/by/4. 0/) DOI: http://dx.doi.org/10.22159/ajpcr.2017.v10i12.20731

\section{INTRODUCTION}

Wound healing involves various processes, cells, and mediators that help to restore structure and function of the damaged tissue [1]. The processes of healing such as inflammation, wound contraction, epithelialization, and remodeling occur simultaneously, resulting in closure of the wound [2]. Any deviation from normal process adversely affects wound healing [3].

Various factors can result in delayed or non-healing of the wound [3]. Wound impairs the quality of life [4]. The management of burn wound is a challenge since it has high morbidity and mortality. Delayed and non-healing burn wound is associated with high risk of mortality [5-7]. Therefore, for improving the management of wound including burn wound, acceleration of wound closure and healing is essential.

Various agents have been used to expedite the healing process which is either proceeding normally or delayed [8-14]. Traditional medicine involves the use of medicinal herbs as they are easily accessible and cheap. The plant Cyanotis cristata belongs to the family Commelinaceae. A member of this family, Commelina benghalensis possess wound healing activity [15]. The root paste of $C$. cristata is used for relief of swelling and snake bite [16]. C. cristata leaves possess antioxidant effect [17]. Phytochemical analysis of the plant has shown the presence of flavonoids and tannins [18]. There is abundant literature showing that flavonoids and tannins have wound healing property [19-21].

A thorough literature search revealed no documentation of wound healing activity of $C$. cristata. Therefore, we evaluated the effect of topical administration of ethanolic extract of leaves of $C$. cristata on wound healing in Wistar rats.

\section{MATERIALS AND METHODS}

Materials

Ketamine (Neon Laboratories Ltd., Thane), xylazine (Indian Immunological Limited, Hyderabad), paraffin wax (Meta Wares India Private Limited, Delhi), silver sulfadiazine (JK Biochem Health Care Pvt. Limited, Uttar Pradesh), and ethyl alcohol (Hi-tech Chemicals, Mumbai) were used in the study.

\section{Animals}

Healthy, adult Wistar rats, either gender, reared in the Central Animal Research Facility, Manipal, with weight ranging from 180 to $200 \mathrm{~g}$ were used. Animals were kept in separate cages which had sterile husk bedding under standard environment conditions [22]. Food and water were administered freely. The research work was undertaken following approval from the Institutional Animal Ethics Committee, Manipal (letter number IAEC/KMC/82/2014).

\section{Preparation of extract}

The plant, C. cristata, was obtained locally and validated by a Professor of botany, Udupi. The leaves were kept in a shaded area to allow for drying. Dried leaves were powdered. Soxhlet extraction of $200 \mathrm{~g}$ powder with $95 \%$ ethanol at $60-80^{\circ} \mathrm{C}$ for $30-40 \mathrm{~h}$ was done [23]. This was followed by distillation, and later, heating on a water bath below $50^{\circ} \mathrm{C}$. The amount of extract obtained was approximately $10 \%(\mathrm{w} / \mathrm{w})$. 
Preparation of formulation

White soft paraffin was triturated with ethanolic extract of $C$. cristata leaves to obtain a different concentration of ointment on a w/w basis, namely, $0.5 \%, 1 \%$, and $2 \%$ ointment [24]. The prepared herbal ointment was put in an airtight, appropriately labeled, plastic container and was maintained at room temperature.

\section{Study design}

Three models of the wound were used - incision, excision, and burn wound. A total of 90 animals were used. Each model had 30 rats which were allocated randomly into 5 groups. Each group had 6 rats. Drugs were applied topically in each model as follows:

Control group - paraffin wax, standard - silver sulfadiazine, and test Groups III (test 1 ), IV(test 2 ), and V (test 3 ) received - $0.5 \%, 1 \%$, and $2 \%$ of the extract, respectively.

\section{Incision wound mode}

Under ketamine anesthesia ( $80 \mathrm{mg} / \mathrm{kg}$, intraperitoneally [i.p.]), the back of each rat was shaved. Two full thickness, straight incision $6 \mathrm{~cm}$ long, on either side of midline was made. They were sutured intermittently, $1 \mathrm{~cm}$ apart [9]. Removal of sutures was on $7^{\text {th }}$ day. Drugs were applied once daily on the wound upto nine days post-wounding. On the $10^{\text {th }}$ day, breaking strength was assessed using water flow technique of Lee [11].

\section{Excision wound model}

A $500 \mathrm{~mm}^{2}$ round area of full thickness skin was excised from an area marked out by a seal having a diameter of $2.5 \mathrm{~cm}$ on the dorsum between the scapulas following administration of ketamine i.p. [25]. Drugs were applied daily up to the 21st post-operative day or until total healing, whichever was earlier. The wound was traced on alternate day from day 0 to 21st post-operative day, or till, the wound was healed and fixed on a graph paper. The rate of contraction was expressed as a percentage of the initial area of wound [26]. The time (days) taken for eschar to fall was epithelialization period [26].

\section{Burn wound model}

Under i.p. ketamine xylazine anesthesia $(0.1 \mathrm{ml} / 100 \mathrm{~g} ; 91 \mathrm{mg} / \mathrm{kg}$ ketamine and $9.1 \mathrm{mg} / \mathrm{kg}$ xylazine), molten wax $\left(80^{\circ} \mathrm{C}\right)$ was poured through a metal cylinder having a circular opening of $500 \mathrm{~mm}^{2}$. After 8 minutes, the cylinder and wax were removed to produce a burn wound of partial thickness [21]. Drugs were administered and parameters measured as described above for excision wound [27]. In both excision and burn wound, granulation tissue was obtained under ketamine anesthesia $(80 \mathrm{mg} / \mathrm{kg}$, i.p.) using a punch biopsy needle following completion of healing and subjected to histopathological analysis [28]

\section{Statistics}

Data were expressed as mean \pm standard error of mean. One-way analysis of variance followed by Tukey's post hoc test was used to analyze data. $P<0.05$ was considered as statistically significant.

\section{RESULTS}

\section{Incision wound model}

The wound of rats in control group had a breaking strength of $322.59 \pm 4.44$ g. In all test groups, mean breaking strength was significantly $(\mathrm{p}<0.001)$ more than control and standard groups. It was significantly $(\mathrm{p}<0.001)$ better in rats who received $2 \%$ preparation as compared to rats treated with $0.5 \%$ and $1 \%$ preparation (Table 1 ).

\section{Excision wound model}

\section{Period of epithelialization}

The mean period of epithelialization in control group was $18.83 \pm 0.60$ days. It was significantly lower $(\mathrm{p}<0.001)$ in all test groups relative to control and standard (Table 2).
Table 1: Effect of ethanolic extract of leaves of $C$. cristata on the breaking strength of a ten day old incision wound in rats

\begin{tabular}{ll}
\hline Group (n=6); drug & $\begin{array}{l}\text { Breaking strength (g) } \\
\text { Mean } \pm \text { SEM }\end{array}$ \\
\hline Control; paraffin wax & $322.59 \pm 4.44$ \\
Standard; silver sulfadiazine & $323.06 \pm 5.45$ \\
Test 1 ; C. cristata leaves (0.5\% ointment) & $388.18 \pm 3.84^{*, * *}$ \\
Test 2; C. cristata leaves (1\% ointment) & $421.58 \pm 4.39^{*, * *, \pi}$ \\
Test 3 ; C. cristata leaves (2\% ointment) & $457.53 \pm 4.19^{*, * *, \pi, \S}$ \\
\hline
\end{tabular}

Values are mean \pm SEM. Statistics - one-way ANOVA followed by Tukey's post hoc test. ${ }^{*} \mathrm{p}<0.001$ versus control, ${ }^{* *} \mathrm{p}<0.001$ versus standard, $\mathrm{p}<0.001$ versus test $1,{ }^{8} \mathrm{p}<0.001$ versus test $2 . \mathrm{n}=$ Number of rats in each group, $C$. cristata: Cyanotis cristata, SEM: Standard error of the mean

Table 2: Effect of ethanolic extract of leaves of $C$. cristata on the period of epithelialization in an excision wound in rats

\begin{tabular}{ll}
\hline Group (n=6); drug & $\begin{array}{l}\text { Period of } \\
\text { epithelialization (days) } \\
\text { Mean } \pm \text { SEM }\end{array}$ \\
\hline Control; paraffin wax & $18.83 \pm 0.60$ \\
Standard; silver sulfadiazine & $18.50 \pm 0.76$ \\
Test 1; C. cristata leaves (0.5\% ointment) & $12.33 \pm 0.42^{*, * *}$ \\
Test 2; . cristata leaves (1\% ointment) & $12.00 \pm 0.44^{*, * *}$ \\
Test 3; C. cristata leaves (2\% ointment) & $11.00 \pm 0.36^{*, * *}$ \\
\hline
\end{tabular}

Values are mean \pm SEM. Statistics - one-way ANOVA followed by Tukey's post hoc test, ${ }^{*} \mathrm{p}<0.001$ versus control, ${ }^{* *} \mathrm{p}<0.001$ versus standard. $\mathrm{n}=$ Number of rats in each group, C. cristata: Cyanotis cristata, SEM: Standard error of the mean

\section{Rate of wound contraction}

Wound contraction rate $(\%)$ on the $4^{\text {th }}$ and $8^{\text {th }}$ day was significantly $(p<0.001)$ greater in rats who received $2 \%$ preparation of extract than other groups (Table 3). It was complete on day 12 in rats treated with $2 \%$ extract and day 16 in rats treated with $0.5 \%$ and $1 \%$ extract (Table 3).

\section{Burn wound model}

\section{Period of epithelialization}

Epithelialization occurred in a significantly $(\mathrm{p}<0.001)$ shorter period of time in all test groups as compared to control and standard groups (Table 4).

\section{Rate of wound contraction}

On the day $4,8,12$, and 16 , contraction of wound was significantly more $(\mathrm{p}<0.05)$ in rats treated with test drug as compared to the rats in control group. Furthermore, on these days, rats treated with $2 \%$ preparation showed faster healing than the rats treated with $0.5 \%$ and $1 \%$ preparation (Table 5 ).

\section{Histopathological evaluation}

Granulation tissue obtained from excision and burn wound was examined under light microscope.

\section{Excision wound (Fig. 1)}

Control group showed dermal scar tissue effacing the adnexal structures (Fig. 1a). In standard group treated with silver sulfadiazine, there was a focally eroded epidermis overlying the dermal stroma showing a fibrotic scar tissue (Fig. 1b). Test group treated with $0.5 \%$ extract of $C$. cristata showed focally atrophied epidermis overlying dermis with early scar tissue formation and minimal inflammatory cells (Fig. 1c). Wounds of rats treated with $1 \%$ extract showed regular epidermis overlying granulation tissue with prominent capillary proliferation (Fig. 1d). In the section of wound in rats treated with $2 \%$ extract, epidermis ranged from regular to focally eroded with dermal granulation tissue (Fig. 1e). 
Table 3: Effect of ethanolic extract of $C$. cristata leaves on contraction rate of an excision wound in rats

\begin{tabular}{|c|c|c|c|c|}
\hline \multirow[t]{2}{*}{ Group (n=6); drug } & \multicolumn{4}{|c|}{$\begin{array}{l}\text { Wound contraction rate }(\%) \\
\text { Mean } \pm \text { SEM }\end{array}$} \\
\hline & $4^{\text {th }}$ day & $8^{\text {th }}$ day & $12^{\text {th }}$ day & $16^{\text {th }}$ day \\
\hline Control; paraffin wax & $23.00 \pm 0.25$ & $48.66 \pm 0.33$ & $86.16 \pm 0.30$ & $92.16 \pm 0.40$ \\
\hline Standard; silver sulfadiazine & $23.66 \pm 0.42$ & $50.00 \pm 0.57$ & $87.33 \pm 0.42$ & $94.16 \pm 0.40^{*}$ \\
\hline Test 1 ; $C$. cristata leaves ( $0.5 \%$ ointment) & $44.16 \pm 0.47^{*, * *}$ & $68.16 \pm 0.30^{*, * *}$ & $87.33 \pm 0.49$ & $100^{*, * *}$ \\
\hline Test $2 ; C$. cristata leaves ( $1 \%$ ointment) & $48.50 \pm 0.22^{*, * *, \pi}$ & $73.16 \pm 0.30^{*, * *, \pi}$ & $92.33 \pm 0.42^{*, * *, \pi}$ & $100^{*, * *}$ \\
\hline Test 3; C. cristata leaves ( $2 \%$ ointment) & $54.33 \pm 0.42^{*, * *, \pi, \S}$ & $74.66 \pm 0.49^{* * * *, \pi, s}$ & $100^{*, * *, \pi, \S}$ & - \\
\hline
\end{tabular}

Values are mean \pm SEM. Statistics - one-way ANOVA followed by Tukey's post hoc test. $\mathrm{p}<0.001$ versus control, $\mathrm{P}<0.05$ versus standard, " $\mathrm{p}<0.001$ versus test 1 , ${ }^{8} \mathrm{p}<0.001$ versus test 2, n=Number of rats in each group, $C$. cristata: Cyanotis cristata, SEM: Standard error of the mean

Table 4: Effect of ethanolic extract of $C$. cristata leaves on epithelialization of burn wound in rats

\begin{tabular}{ll}
\hline Group (n=6); drug & $\begin{array}{l}\text { Period of } \\
\text { epithelialization (days) } \\
\text { Mean } \pm \text { SEM }\end{array}$ \\
\hline Control; paraffin wax & $17.66 \pm 0.95$ \\
Standard; silver sulfadiazine & $17.16 \pm 0.60$ \\
Test 1; C. cristata leaves (0.5\% ointment) & $14.83 \pm 0.79^{*, * *}$ \\
Test 2; C. cristata leaves (1\% ointment) & $13.16 \pm 0.70^{*, * *, \pi}$ \\
Test 3; C. cristata leaves (2\% ointment) & $12.66 \pm 0.55^{*, * * \pi}$ \\
\hline
\end{tabular}

Values are mean \pm SEM. Statistics - one-way ANOVA followed by Tukey's post hoc test. ${ }^{*} p<0.001$ versus control, ${ }^{* *} \mathrm{p}<0.001$ versus standard, "p $<0.001$ versus test $1, \mathrm{n}=$ Number of rats in each group, C. cristata: Cyanotis cristata, SEM: Standard error of the mean

\section{Burn wound (Fig. 2)}

Section of wound from control group showed atrophied epidermis with scar tissue formation and minimal inflammation (Fig. 2a). The wound of rats treated with silver sulfadiazine had eroded epidermis with features of regeneration. The dermal stroma showed scar tissue with effaced adnexae and no inflammation (Fig. 2b). The epidermis of wound of rats treated with $0.5 \%$ extract showed dermis with neutrophils and granulation tissue (Fig. 2c). In the test group treated with $1 \%$ extract, there was atrophic epidermis with dermal scar tissue and granulation tissue (Fig. 2d). Test group treated with 2\% extract had an epidermis which was regular with an increase in dermal granulation tissue with minimal inflammation (Fig. 2e).

\section{DISCUSSION}

The effect of C. cristata on healing of incision, excision, and burn wounds in rats was studied. The mean breaking strength of incision wound in rats of extract treated groups was significantly higher than other groups. The final wound strength depends on quantity and maturation of collagen. Thus, it is a result of fibroplasia and remodeling [29]. Reactive oxygen species (ROS) generated following wounding can adversely affect healing by various mechanisms including upregulation of matrix degrading enzymes [30-32]. Antioxidant effect of plant extract has been shown to promote healing of wounds [33]. The extracts of leaves of $C$. cristata have rich antioxidant property [17]. In a previous study, phytochemistry of $C$. cristata revealed the presence of flavonoids and tannins [18]. Flavonoids increase collagen content of wound through multiple mechanisms. Injury results in the generation of ROS that impairs the strength of collagen making it susceptible to lysis. Flavonoids, being antioxidants, prevent this and increase the viability of collagen [34]. Further, Vitamin C, that is required for collagen formation and maturation, is up-regulated in flavonoid-treated wound [35]. Flavonoids have also been shown to increase the viability and proliferation of fibroblasts [36]. Tannins have antioxidant effect and may act in similar fashion to promote collagen deposition [37]. They also increase angiogenesis by increasing vascular endothelial growth factor formation, thus maintaining adequate supply of oxygen necessary for collagen stability [38].

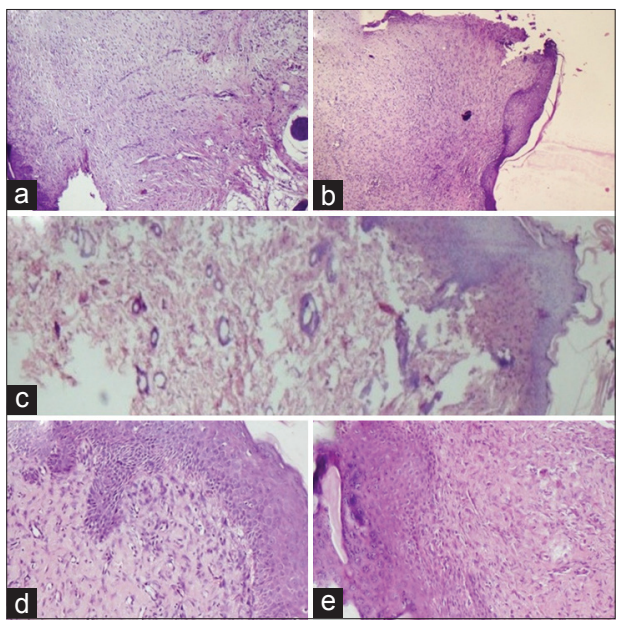

Fig. 1: Histopathology of excision wound. (a) Control group. (b) Standard group. (c) Test group treated with $0.5 \%$ extract. (d) Test group treated with $1 \%$ extract. (e) Test group treated with $2 \%$ extract

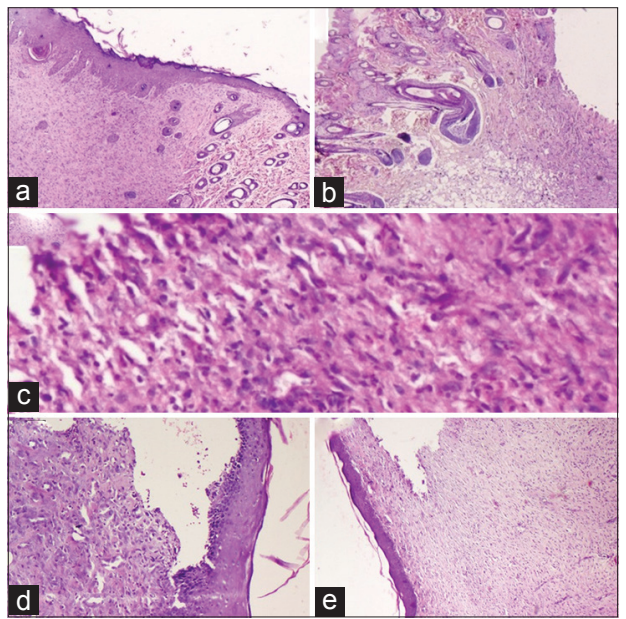

Fig. 2: Histopathology of burn wound. (a) Control group. (b) Standard group. (c) Test group treated with $0.5 \%$ extract. (d) Test group treated with $1 \%$ extract. (e) Test group treated with $2 \%$ extract

Epithelialization is the process, wherein the stratified epithelium is restored following injury [39]. C. cristata leaves decreased the period of epithelialization of excision wound in rats. This process involves migration and proliferation of epithelial cells [39]. Flavonoids induce various signalling pathways involved in cell migration - extracellular signal-regulated kinase, protein kinase B, and NADPH oxidase. This results in increased level of E-cadherin, a junctional protein, which 
Table 5: Effect of ethanolic extract of $C$. cristata leaves on contraction of burn wound in rats

\begin{tabular}{|c|c|c|c|c|}
\hline \multirow[t]{2}{*}{ Group (n=6); Drug } & \multicolumn{4}{|c|}{$\begin{array}{l}\text { Wound contraction }(\%) \\
\text { Mean } \pm \text { SEM }\end{array}$} \\
\hline & $4^{\text {th }}$ day & $8^{\text {th }}$ day & $12^{\text {th }}$ day & $16^{\text {th }}$ day \\
\hline Control; paraffin wax & $17.50 \pm 0.42$ & $37.42 \pm 0.26$ & $61.66 \pm 0.21$ & $84.00 \pm 0.68$ \\
\hline Standard; silver sulfadiazine & $19.33 \pm 0.42 *$ & $40.83 \pm 0.31^{*}$ & $66.17 \pm 0.30 *$ & $85.17 \pm 0.60$ \\
\hline Test $1 ;$ C. cristata leaves ( $0.5 \%$ ointment) & $21.23 \pm 0.36^{*, * *}$ & $46.67 \pm 0.49^{*, * *}$ & $73.47 \pm 0.27^{*, * *}$ & $100^{*, * *}$ \\
\hline Test $2 ;$ C. cristata leaves (1\% ointment) & $23.83 \pm 0.40^{*, * *, \pi}$ & $51.17 \pm 0.47^{*, * *, \pi}$ & $88.33 \pm 0.49 *, * *, \pi$ & $100^{*, * *}$ \\
\hline Test $3 ;$. cristata leaves ( $2 \%$ ointment) & $25.83 \pm 0.30 *, * *, \pi, \S$ & $76.33 \pm 0.21^{*, * *, \pi, \S}$ & $96.50 \pm 0.22^{*, * *, \pi, \S}$ & $100^{*, * *}$ \\
\hline
\end{tabular}

Values are mean \pm SEM. Statistics - one-way ANOVA followed by Tukey’s post hoc test; ${ }^{*} \mathrm{p}<0.05$ versus control, ${ }^{* *} \mathrm{p}<0.05$ versus standard, ${ }^{\llbracket p}<0.05$ versus test $1,{ }^{\S} \mathrm{p}<0.05$ versus test 2. $\mathrm{n}=$ Number of rats in each group, C. cristata: Cyanotis cristata, SEM: Standard error of the mean

plays an important role in collective migration of keratinocytes. Further, it also induces several metalloproteinases, which degrades extracellular matrix, thereby facilitating migration [40]. Furthermore, both tannins and flavonoids increase collagen deposition [34-37] that provides scaffolding for the process of epithelialization [41].

Wound contraction, manifesting as shrinkage of wound area, starts around 5th day post wounding [42]. C. cristata leaves significantly accelerated wound healing in excision wound as shown by greater percentage of wound contraction in our study. This enhanced wound contraction may be either due to enhanced activity of fibroblasts which provide the force responsible for wound contraction, or it may also be due to increased deposition of collagen. The force generated by fibroblasts, thus compacting the formed collagen [43].

Flavonoids and tannins are considered to be groups rather than individual entities $[44,45]$. Thus, the individual member(s) responsible for the enhanced wound healing effect needs to be determined. Infection may prolong the healing by prolonging inflammation. Plants with antibacterial action have been shown to promote wound healing [46]. Flavonoids and tannins can prevent bacterial infection of wound. This is another mechanism by which they can enhance healing [47]. However, no group in our study showed any sign of infection.

In burn wound model, $C$. cristata extract-treated group enhanced epithelialization as well as rate of wound contraction. Burn wound is usually associated with ischemia followed by restoration of blood flow. This results in the generation of ROS that can delay healing [48]. C. cristata leaves have been demonstrated to have antioxidant effect [17]. Furthermore, phytoconstituents such as flavonoids and tanninscan accelerate healing [18]

Effect of silver sulfadiazine effect on healing is a controversial topic with evidence for both its healing and anti-healing effect. Studies have shown that silver sulfadiazine enhances healing by stimulating epithelial migration and granulation tissue formation while another reported that it inhibits fibroblast proliferation and collagen maturation, while some studies demonstrated the effect that was comparable to control [49-51]. In our study, wound healing parameters in silver sulfadiazine-treated group and control group were comparable.

The limitation of the study was that estimation was not done of hydroxyproline (a marker of collagen content) and antioxidants in granulation tissue of wound.

\section{CONCLUSION}

Treatment with ethanolic extract of $C$. cristata leaves topically enhanced wound strength and accelerated healing of incision, excision, and burn wounds in rats. Further studies are required to isolate and evaluate individual phytoconstituents in C. cristata for their wound healing potential.

\section{REFERENCES}

1. Lazarus GS, Cooper DM, Knighton DR, Margolis DJ, Pecoraro RE, Rodeheaver $\mathrm{G}$, et al. Definitions and guidelines for assessment of wounds and evaluation of healing. Arch Dermatol 1994;130(4):489-93.

2. Brown H. Wound healing research through ages. In: Cohen IK, Diegelmann RF, Lindblad WJ, editors. Wound Healing: Biochemical and Clinical Aspects. 1st Philadelphia, PA: W. B. Saunders; 1992. p. 518 .

3. Guo S, Dipietro LA. Factors affecting wound healing. J Dent Res 2010;89(3):219-29.

4. Vowden P. Hard-to-heal wounds made easy. Int Wound J 2011; 2(4):26. Available from: http://www. woundsinternational. com/media/ issues/514/files/content_10140.pdf. [Last cited on 2016 Aug 18].

5. Tiwari VK. Burn wound: How it differs from other wounds? Indian J Plast Surg 2012;45(2):364-73.

6. Nitzschke SL, Aden JK, Serio-Melvin ML, Shingleton SK, Chung KK, Waters JA, et al. Wound healing trajectories in burn patients and their impact on mortality. J Burn Care Res 2014;35(6):474-9.

7. Desai MH, Herndon DN, Broemeling L, Barrow RE, Nichols RJ Jr, Rutan RL. Early burn wound excision significantly reduces blood loss. Ann Surg 1990;211(6):753-9.

8. Mather WD, Sherman M, Fryezkowski A, Jester JV. Dose dependent effect of epidermal growth factor on corneal wound healing. Invest Opthalmol Vis Sci 1989;30(11):2403-6.

9. Ehrlich HP, Hunt TK. Effects of cortisone and vitamin A on wound healing. Ann Surg 1968;167(3):324-8.

10. Raju SS, Kulkarni DR. Vitamin A reverses the wound healing suppressant effect of cyclophosphamide. Indian J Pharmacol 1986;18:154-7.

11. Lee KH. Studies on the mechanism of action of salicylates 3. Effect of vitamin A on the wound healing retardation action of aspirin. J Pharm Sci 1968;57(7):1238-40.

12. Udupa SL, Shaila HP, Udupa AL, Ramesh KV, Kulkarni DR. Effect of bothropase on wound healing. Biochem Arch 1991;7:207-12.

13. William RH, Bissell GW. Effect of topical application of vitamins and some other chemicals on the healing of wound. Arch Surg 1994;49:225-30

14. Rao CM, Kumar A, Kulkarni DR. Effects of enfenamic acid and its zinc salt on wound-healing. Indian J Physiol Pharmacol 1988;32(1):61-6.

15. Sambrekar SN, Patil PA, Patil S. Wound healing activity of root extracts of Commelina benghalensis Linn. Res J Pharm Technol 2011;4(11):1772-6

16. Karthik S, Subramaniam M, Ravikumar S, Dhamotharan R. Medicinal plants and their uses: A study of twelve sacred groves in Cuddalore and Villupuram districts, Tamil Nadu, India. J Res Int Educ 2016;2(5):95-102.

17. Prabhune AM, Jadhav SN, Kadam DA, Nandikar MD, Aparadh VT. Free radical scavenging (DPPH) and ferric reducing ability (FRAP) of some Commelinaceae members. Int J Biol Pharm Allied Sci 2013;2(5):1128-34.

18. Kharade AS, Jadhav SS, Jadhav SN, Thite SV, Aparadh VT. Phytochemical investigation in Commelinea bengalensis \& Cyanotis cristata. Int Res J Pharm Appl Sci 2013;3(1):46-8.

19. Choudary JP. Wound healing activity of the ethanolic extract of Terminalia chebularetz. Int J Pharm Bio 2011;2(1):48-52.

20. Anitha S, Suresh GS, Ramaiah M, Vaidya VP. Extraction, isolation and 
wound healing activity of flavonoid from Coscinium fenestratum. Res $\mathrm{J}$ Pharm Biol Chem Sci 2011;2(3):1090-5

21. Nurdiana S, Marziana N. Wound healing activities of Melastoma malabathricum leaves extract in Sprague Dawley rats. Int J Pharm Sci Rev Res 2013;20(2):20-3.

22. Bairy KL, Kumar SM, Savin CG, Kumar KN, Avinash M. Effect of different formulations of silver sulphadiazine cream on experimentally induced burn wound healing. Res J Pharm Biol Chem Sci 2012;3:884-9.

23. Babu G, Sanjeeva R, Bairy KL. Effect of Tridax procumbens on burn wound healing. Indian Drugs 2003;40(8):488-91.

24. Panda P. Formulation and evaluation of topical dosage form of Pandanus fascularis Lam and their wound healing activity. Drug Interv Today 2010;2(9):417-20.

25. Morton JJ, Malone MH. Evaluation of vulneray activity by an open wound procedure in rats. Arch Int Pharmacodyn Ther 1972;196(1):117-26.

26. Kumar MS, Kirubanandan S, Sripriya R, Sehgal PK. Triphala promotes healing of infected full-thickness dermal wound. J Surg Res 2008;144(1):94-101.

27. Shenoy S, Sukesh B, Vinod MS, Shruthi N, Amberkar M, Amuthan A. Effect of ethanolic extract of Plectranthus amboinicus leaf on healing of burn wound in wistar rats. Int J Appl Biol Pharm Technol 2012;3(3):32-5.

28. Gutierrez RM, Solis RV. Wound healing properties of triterpenes from Buddleia scordioides in diabetic rats. Pharm Biol 2008;46(9):647-53.

29. Kumar V, Abbas K, Fausto N, Aster JC, editors. Tissue renewal, regeneration, and repair. In: Robbins and Cotran Pathological Basis of Disease. 8th ed. Gurgaon: Reed Elsevier India Private Limited; 2011. p. 79-110.

30. Martin A. The use of antioxidants in healing. Dermatol Surg 1996;22(2):156-60.

31. Wenk J, Foitzik A, Achterberg V, Sabiwalskiy A, Dissemond J, Meewes C, et al. Selective pick-up of increased iron by deferoxamine coupled cellulose abrogates the iron-driven induction of matrixdegrading metalloproteinase-1 (MMP-1) and lipid peroxidation in human dermal fibroblasts in vitro - A new dressing concept. J Invest Dermatol 2001;116:833-9.

32. O'Toole EA, Goel M, Woodley DT. Hydrogen peroxide inhibits human keratinocyte migration. Dermatol Surg 1996;22(6):525-9.

33. Farahpour MR, Emami P, Ghayour SJ. In vitro antioxidant properties and wound healing activity of hydroethanolic turmeric rhizome extract (Zingiberaceae). Int J Pharm Pharm Sci 2014;6(8):474-8.

34. Ambiga S, Narayanan R, Gowri D, Sukumar D, Madhavan S. Evaluation of wound healing activity of flavonoids from ipomoea carnea Jacq. Anc Sci Life 2007;26(3):45-51.

35. Gupta A, Kumar R, Pal K. Singh V, Banerjee PK, Sawhney RC. Influence of sea buckthorn (Hippophae rhamnoides L.) Flavones on dermal wound healing in rats. Mol Cell Biochem 2006;290(1-2):193-8.

36. Stipcevic T, Piljac J, Vanden Berghe D. Effect of different flavonoids on collagen synthesis in human fibroblasts. Plant Foods Hum Nutr 2006;61(1):29-34

37. de Jesus NZ, de Souza Falcão H, Gomes IF, de Almeida Leite TJ, de Morais Lima GR, Barbosa-Filho JM, et al. Tannins, peptic ulcers and related mechanisms. Int J Mol Sci 2012;13(3):3203-28.

38. Li K, Diao Y, Zhang H, Wang S, Zhang Z, Yu B, et al. Tannin extracts from immature fruits of Terminalia chebula Fructus Retz. Promote cutaneous wound healing in rats. BMC Complement Altern Med 2011;11:86.

39. Pastar I, Stojadinovic O, Yin NC, Ramirez H, Nusbaum AG, Sawaya A, et al. Epithelialization in wound healing: A comprehensive review. Adv Wound Care (New Rochelle) 2014;3(7):445-64.

40. Bui NT, Ho MT, Kim YM, Lim Y, Cho M. Flavonoids promoting HaCaT migration: II. Molecular mechanism of 4, 6,7-trimethoxyisoflavone via NOX2 activation. Phytomedicine 2014;21(4):570-7.

41. Cohen IK, Diegelmann RF, Lindblad WJ. Wound Healing: Biochemical and Clinical Aspects. Philadelphia, PA: W.B. Saunders Company; 1992. p. 344-55.

42. Mendonça RJ, Coutinho-Netto J. Cellular aspects of wound healing. An Bras Dermatol 2009;84(3):257-62.

43. Ehrlich HP, Hunt TK. Collagen organization critical role in wound contraction. Adv Wound Care (New Rochelle) 2012;1(1):3-9.

44. Kumar S, Pandey AK. Chemistry and biological activities of flavonoids: An overview. ScientificWorldJournal 2013;2013:162750.

45. Chung KT, Wong TY, Wei CI, Huang YW, Lin Y. Tannins and human health: A review. Crit Rev Food Sci Nutr 1998;38(6):421-64.

46. Sukantha TA, Shubashini KS, Ravindran NT. Antibacterial activity of selected medicinal plant in traditional treatment of wound infection in southeast India. Int J Pharm Pharm Sci 2014;6(11):511-3.

47. Thakur R, Jain N, Pathak R, Sandhu SS. Practices in wound healing studies of plants. Evid Based Complement Alternat Med 2011;2011:438056.

48. Demlin RH. Burns and other thermal injuries. In: LW GM, editorsCurrent Surgical Diagnosis and Treatment. New York, USA: McGraw Hill; p. 267-6.

49. Hoekstra MJ, Andrews L. Effect of silver sulfadiazine on histopathologic parameters of burn wound in pig. Burns 2003;29:544-7.

50. La L, Jiang X, Huo Q. The preparation of collagen burn pellicle of compound sulfadiazine silver and assessment of its efficacy in an animal experiment on deep partial thickness burn wound. Hua Xi Yi Ke Da Xue Xue Bao 2001;32(3):419-23.

51. Lal S, Barrow RE, Wolf SE, Chinkes DL, Hart DW, Heggers JP, et al. Biobrane improves wound healing in burned children without increased risk of infection. Shock 2000;14(3):314-8. 